\title{
Characterization of indigenous cattle genotypes based on linear body traits in the humid tropics
}

${ }^{* 1}$ Nosike, R. J., ${ }^{1}$ Nwakpu, O. F., ${ }^{2}$ Isaac, U. C., ${ }^{1}$ Akinsola, K. L, ${ }^{3}$ Nwose, R. N. and ${ }^{4}$ Onunkwo, D. N.

${ }^{I}$ Department of Animal Breeding and Physiology, Michael Okpara University of Agriculture, Umudike, Abia State, Nigeria.

${ }^{2}$ Department of Animal Science, Nnamdi Azikiwe, University, Awka, Anambra State ${ }^{3}$ Department of Agriculture, Alex Ekweume University Ikwo, Ebonyi State, Nigeria.

${ }^{4}$ Department of Animal Nutrition and Forage Science,

Michael Okpara University of Agriculture, Umudike,

Abstract Abia State, Nigeria.

Selection for trait of interest is a major problem in cattle production when faced with the challenge of varied growth traits in different genotypes. Low understanding of the production potentials of these cattle breeds constitute problems in effective improvement of physical body characteristics. A total of 18 cattle was used to characterize the Nigerian local cattle genotypes based on quantitative traits. Three genotypic groups \{White Fulani (WF), N'Dama (ND) and White Fulani $x N^{\prime}$ Dama (WFxND)\} crosses were used for the experiment. Experimental design was a completely randomized design (CRD) with genotypic group as major factor of interest. Quantitative traits measured were body length $(B D L)(\mathrm{cm})$, hip height $(H H T)(\mathrm{cm})$, heart girth $(H G)(\mathrm{cm})$, horn length $(H L)(\mathrm{cm})$, tail length $(T L)(\mathrm{cm})$, ear length $(E l)(\mathrm{cm})$ and neck length $(\mathrm{NL})$. Results showed that there were significant differences $(p<0.05)$ in body length in weeks $99-111$ and $112-124$ with the White Fulani and N'Dama genotypes having longer bodies. The values ranged from 33.00 to $39.29 \mathrm{~cm}$ in WF, 39.49 to $39.59 \mathrm{~cm}$ in N'Dama and, 18.25 to 32.90 in WF x ND. There were significant $(p<0.05)$ differences in hip height of cattle in age interval of 99-111 and 112-124 weeks of age, with the White Fulani and N'Dama genotypes having highest hip. The genotypes showed significant $(p<0.05)$ differences in heart girth in 99 and 124 WOA with the White Fulani and N'Dama genotypes having widest heart girth. The genotypes showed significant $(p<0.05)$ differences in horn length in all the weeks with White Fulani showing superiority. The genotype had longer horns in the White Fulani and followed by WF $x$ ND across the week intervals. The values ranged from 14.99 to $15.20 \mathrm{~cm}$ in $W F, 5.75$ to $10.19 \mathrm{~cm}$ in N'Dama and, 3.00 to 4.29 in WF $x$ ND. The tail length of the three genotypes showed significant $(p<0.05)$ differences in 99-111 and 112-124 WOA. Higher values were obtained in White Fulani genotype which showed longer tails than the N'Dama and WF $x$ ND. There were significant $(p<0.05)$ differences in neck length of the cattle genotypes in 112-124 WOA. Higher values were obtained in White Fulani genotype which showed longer neck than the N'Dama and WF $x$ ND. White Fulani could be used to enhance growth of Nigerian indigenous cattle in the study area. The present findings could assist in the design of longterm genetic improvement programmes for cattle production in Nigeria.

Keywords: Nigeria indigenous cattle, genotypes, quantitative traits.

\section{Introduction}

Tropical cattle require the development of a very good model for its genetic improvement (Rege and Tawah, 1999).
Nigeria is endowed with varied ecological zones with diverse animal genetic resources of the local breeds. These local breeds possess genes relevant for their 


\section{Characterization of indigenous cattle genotypes based on linear body traits}

survival and adaptation to their environment and local breeding goals. In Nigeria, there is need to improve animal production to meet protein requirement. The choice of the right type of animals to be raised in the area where it is best adapted which result in higher productivity and performance is very important. To improve effectively on physical body characteristics of cattle, there is need to understand the production potentials of these cattle breeds. Linear measurements are divided into two groups, which include skeletal and tissue measurements. Skeletal measurements include all the height and length measurements while tissue measurements include heart girth, chest depth, punch girth, and width of hips (Blackmore et al., 1995). These body measurements can be further divided into horizontal measurements like body length (BDT) and head to shoulder (HDS) and vertical measurements like hip height (HPH) and chest depth. The local breeds of animals in Nigeria deserve improvement in their genetic profile and physiological status (Nosike et al., 2013). Also, the main purpose of animal breeding practices is to improve traits of economic value (Mendes et al., 2005). The study therefore aimed to characterize three genotypes of indigenous cattle based on quantitative traits.

\section{Materials and methods}

This experiment was carried out at the Cattle Unit of Teaching and Research Farm of Michael Okpara University of Agriculture, Umudike, Abia State, Nigeria. Umudike is located on latitude $05^{\circ} \mathrm{C} 28^{\prime}$ North and $07^{\circ} \mathrm{C} 32^{\prime}$ East and lies at an altitude of $122 \mathrm{~m}$ above sea level. This area is situated within the tropical rainforest zone of West Africa which is characterized by long duration of rainfall (April October) and short period of dry season (November-March). Average rainfall is
$2169.8 \mathrm{~mm}$ in $148-155$ rain days. Average ambient temperature is $26^{\circ} \mathrm{C}$ with a range $22^{\circ} \mathrm{C}$ and $30^{\circ} \mathrm{C}$. Its relative humidity ranges from 50 to $90 \%$. These meteorological data were obtained from the meteorological station at the National Root Crops Research Institute, Umudike Abia State (NRCRI, 2017).

Experimental animals and their management

A total of 18 cattle aged between 60 and 72 weeks comprising White Fulani, N'Dama and (N'Dama $\times$ White Fulani) crosses with six cattle per group which was replicated three times with two animals per replicate were used for the experiment. The cattle were sourced from the university farm. They were managed semi-intensively. Iron injection was administered to cattle after collection of blood samples to enable the animals regain themselves.

\section{Experimental design}

The experiment was a completely randomized design, with genotypic group as a single factor of interest. The statistical model was; $\mathrm{Y}_{\mathrm{ij}}=\mu+\mathrm{G}_{\mathrm{i}}++\mathrm{e}_{\mathrm{ij}}$

Where

$Y_{i j}=j^{\text {th }}$ observation in the $i^{\text {th }}$ genotype.

$\mu=$ overall mean

$\mathrm{G}_{\mathrm{i}}=$ effect of $\mathrm{i}^{\text {th }}$ genotype

$\mathrm{E}_{\mathrm{ij}}=$ random error assumed to be independently, identically and normally distributed with zero mean and constant variance.

\section{Data collection}

\section{Parameters measured}

Body length, hip height, heart girth, horn length, tail length, ear length and neck length were measured on individual cattle with the aid of tailor's tape $(\mathrm{cm})$. The animals were made of both male and female. The animals were restricted by the handlers using cattle crush. Measurement were taken early in the morning prior to feeding/grazing. 
Body length (BDL): joint of the scapular to the pin bone.

Hip height (HPH): distance from the platform on which the animals stand to the point of its shoulder.

Heart girth (HG): the body circumference immediately posterior of the front legs or the body circumference on the fore ribs.

Horn length (HL): the length from the base of the horn to the tip of the horn.

Tail length (TL): distance from the base to the end of the tail.

Ear length (EL): distance from the base to the tip of the ear.

Neck length (TL): the length of the neck region from the head to the hump.

\section{Statistical analysis}

Data obtained were statistically analyzed with SPSS (2011). Analysis of variance (ANOVA) procedure appropriate for CRD was used to analyze the data on quantitative traits. Duncan's Multiple Range Test (Duncan, 1955) was used to compare significant means of parameters on three genotypes of cattle.

\section{Results and discussion Body length}

The means of body length (BDL) of the various genotypes are presented in Table 1. The genotypes showed significant $(\mathrm{p}<0.05)$ differences in weeks $99-111$ and $112-124$ with the white Fulani and N'Dama genotypes having longest bodies. The values ranged from 33.00 to $39.29 \mathrm{~cm}$ in WF, 39.49 to $39.59 \mathrm{~cm}$ in N'Dama and, 18.25 to 32.90 in WF $x$ ND. This implies that body length can be used effectively to discriminate among the genotypes in week $99-111$ and $112-124$. Body length as a growth trait is useful in improving the market quality of breeding stocks (Nwachukwu et al., 2011). Body dimensions have been used to indicate breed, origin and relationship through the medium of head measurements (Itty, et al, 1997) or to indicate size. EAAP and FAO have used wither height for example as a prime indicator type (Wilson, 1995).

Table 1: Mean Body length (cm) of White Fulani, N'Dama and White Fulani x N'Dama crosses

\begin{tabular}{lllll}
\hline Age (weeks) & White Fulani & WFXND & N'Dama & SEM \\
\hline $60-72$ & 33.00 & 18.25 & 39.49 & 5.72 \\
$73-85$ & 33.10 & 18.30 & 39.49 & 5.72 \\
$86-98$ & 33.10 & 32.90 & 39.59 & 2.08 \\
$99-111$ & $39.19^{\mathrm{a}}$ & $32.90^{\mathrm{b}}$ & $39.59^{\mathrm{a}}$ & 1.37 \\
$112-124$ & $39.29^{\mathrm{a}}$ & $32.79^{\mathrm{b}}$ & $39.56^{\mathrm{a}}$ & 1.88 \\
\hline
\end{tabular}

$\overline{\text { ab }}$ Means within the rows with different superscripts differ significantly $(\mathrm{P}<0.05)$; SEM - Standard error of the mean, WF x ND = White Fulani x N'Dama crosses

\section{Hip height}

The means of Hip height (HHT) of the various genotypes are presented in Table 2 . There were significant $(\mathrm{p}<0.05)$ differences in Hip height of cattle in age interval of 99111 and $112-124$ weeks of age, with the white Fulani and N'Dama genotypes having highest hip. The lower hip height in the WF $x$ ND cattle indicates low vigour, which may be attributed to breed recombination. The EAAP and FAO have used wither height for example as a prime indicator type (Wilson, 1995). There were no significant ( $>0.05$ ) differences in $\mathrm{HH}$ in the other age groups. 


\section{Characterization of indigenous cattle genotypes based on linear body traits}

Table 2: Means of hip height (cm) of White Fulani, N'Dama and their crosses

\begin{tabular}{lllll}
\hline Age (wks) & White Fulani & WFXND & N'dama & SEM \\
\hline $60-72$ & 42.50 & 35.00 & 47.99 & 2.78 \\
$73-85$ & 42.55 & 35.15 & 47.99 & 2.75 \\
$86-98$ & 42.70 & 35.20 & 48.19 & 2.78 \\
$99-111$ & $48.19^{\mathrm{a}}$ & $35.35^{\mathrm{b}}$ & $48.19^{\mathrm{a}}$ & 2.72 \\
$112-124$ & $48.29^{\mathrm{a}}$ & $36.29^{\mathrm{b}}$ & $48.30^{\mathrm{a}}$ & 3.46 \\
\hline
\end{tabular}

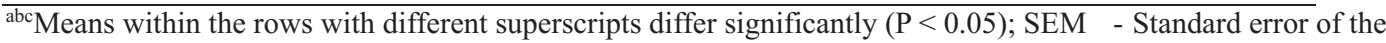
mean, WF x ND = White Fulani x N'Dama crosses

\section{Heart girth}

The means of Heart girth (HG) of the various genotypes are presented in Table 3 . The genotypes showed significant $(\mathrm{p}<0.05)$ differences in Heart girth in 99 and 124 WOA with the white Fulani and N'Dama genotypes having widest heart girth. This implies that heart girth can be used effectively to discriminate among the genotypes in 99 and 124 WOA and heart girth as a growth trait is useful in improving the market quality of breeding stocks (Nwachukwu et al., 2011). Body dimensions have been used to indicate breed, origin and relationship through the medium of head measurements (Itty et al, 1997) or to indicate size. Wilson (1995) reported that wither height has been used as a prime indicator type.

Table 3: Means of heart girth (cm) of white Fulani, N'Dama and their crosses

\begin{tabular}{lllll}
\hline Age (wks) & White Fulani & WFXND & N'dama & SEM \\
\hline $60-72$ & 33.00 & 18.25 & 39.49 & 5.72 \\
$73-85$ & 33.60 & 34.20 & 37.99 & 1.47 \\
$86-98$ & 33.65 & 34.25 & 38.19 & 1.48 \\
$99-111$ & $38.19^{\mathrm{a}}$ & $34.3^{\mathrm{b}}$ & $38.29^{\mathrm{a}}$ & 0.86 \\
$112-124$ & $38.29^{\mathrm{a}}$ & $33.39^{\mathrm{b}}$ & $38.19^{\mathrm{a}}$ & 1.41 \\
\hline
\end{tabular}

${ }^{\mathrm{abc}}$ Means within the rows with different superscripts differ significantly $(\mathrm{P}<0.05)$; SEM - Standard error of the mean, WFXND = White Fulani X N'Dama crosses

\section{Horn length}

The means of horn length (HL) of the various genotypes are presented in Table 4. The genotypes showed significant $(\mathrm{p}<0.05)$ differences in horn length in all the weeks with White Fulani showing superiority. The genotype had longer horns in the white Fulani and followed by WF $x$ ND across the week intervals. The values ranged from
14.99 to $15.20 \mathrm{~cm}$ in WF, 5.75 to $10.19 \mathrm{~cm}$ in N'Dama and, 3.00 to 4.29 in WFxND. The horn length increases with increase in age. Increase in horn length indicates growth of the cattle. Growth is normally accompanied by an orderly sequence of maturational changes and involves accretion of protein and increase in length and size (Gous, 1997).

Table 4: Means of horn length $(\mathrm{cm})$ of white Fulani, N'Dama and their crosses

\begin{tabular}{|c|c|c|c|c|}
\hline Age (weeks) & White Fulani & WDxND & N'dama & SEM \\
\hline $60-72$ & $14.99^{\mathrm{a}}$ & $3.00^{\mathrm{b}}$ & $5.75^{\mathrm{ab}}$ & 2.56 \\
\hline $73-85$ & $14.99^{\mathrm{a}}$ & $3.05^{\mathrm{b}}$ & $5.90^{\mathrm{ab}}$ & 2.55 \\
\hline $86-98$ & $15.19^{\mathrm{a}}$ & $3.15^{\mathrm{b}}$ & $5.95^{\mathrm{ab}}$ & 2.56 \\
\hline $99-111$ & $15.19^{\mathrm{a}}$ & $3.20^{\mathrm{c}}$ & $10.19^{b}$ & 2.21 \\
\hline $112-124$ & $15.20^{\mathrm{a}}$ & $4.29^{\mathrm{c}}$ & $10.19^{\mathrm{b}}$ & 1.70 \\
\hline
\end{tabular}

${ }^{\mathrm{abc}}$ Means within the rows with different superscripts differ significantly $(\mathrm{P}<0.05)$; SEM - Standard error of the mean, WF x ND = White Fulani x N'Dama crosses 


\section{Tail length}

The means of Tail length (TL) of the various genotypes are presented in Table 5. The tail length of the three genotypes showed significant $(\mathrm{p}<0.05)$ differences in $99-111$ and 112-124 WOA. Higher values were obtained in White Fulani genotype which showed longer tails than the N'Dama and WFxND counterpart. The superiority of the White Fulani may be attributed to breed difference.

Table 5: Means of tail length (cm) of white Fulani, N'Dama and their crosses

\begin{tabular}{|c|c|c|c|c|}
\hline Age (wks) & White Fulani & WFXND & N'dama & SEM \\
\hline $60-72$ & 24.75 & 23.00 & 27.99 & 1.43 \\
\hline $73-85$ & 24.80 & 23.10 & 28.09 & 1.43 \\
\hline $86-98$ & 24.90 & 23.15 & 28.09 & 1.42 \\
\hline $99-111$ & $29.09^{\mathrm{a}}$ & $23.25^{\mathrm{c}}$ & $28.19^{\mathrm{b}}$ & 1.15 \\
\hline $112-124$ & $29.09^{\mathrm{a}}$ & $23.19^{c}$ & $28.21^{\mathrm{b}}$ & 1.30 \\
\hline
\end{tabular}

\section{Ear length}

The means of Ear length (EL) of the various genotypes are presented in Table 6. There were significant $(\mathrm{p}<0.05)$ differences in Ear length in cattle genotypes in 112-124 WOA with White Fulani having longer ears than the N'Dama and WFxND counterpart. The values ranged from 7.25 to $19.19 \mathrm{~cm}$ in $\mathrm{WF}$, 6.99 to $7.32 \mathrm{~cm}$ in N'Dama and 6.50 to 7.79 in WFxND The values followed an increasing trend with age which indicates growth (Nosike et al., 2013).

Table 6: Means of ear length (cm) of white Fulani, N'Dama and their crosses

\begin{tabular}{lllll}
\hline Age (wks) & White Fulani & WFxND & N'dama & SEM \\
\hline $60-72$ & 7.25 & 6.50 & 6.99 & 0.54 \\
$73-85$ & 7.30 & 6.60 & 7.19 & 0.53 \\
$86-98$ & 7.35 & 6.65 & 7.19 & 0.54 \\
$99-111$ & 9.09 & 6.80 & 7.29 & 0.51 \\
$112-124$ & $9.19^{\mathrm{a}}$ & $7.79^{\mathrm{b}}$ & $7.32^{\mathrm{b}}$ & 0.40 \\
\hline
\end{tabular}

${ }^{\mathrm{a}-\mathrm{b}}$ Means within the rows with different superscripts differ significantly $(\mathrm{P}<0.05)$; SEM- Standard error of the mean. WF x ND = White Fulani x N'Dama crosses

\section{Neck length}

The means of Neck length (NL) of the various genotypes are presented in Table 7 . There were significant $(\mathrm{p}<0.05)$ differences in neck length of the cattle genotypes in 112-124 WOA. Higher values were obtained in White Fulani genotype which showed longer neck than the N'Dama and WF x ND counterpart.

Table 7: Means of neck length (cm) of white Fulani, N'Dama and their crosses

\begin{tabular}{lllll}
\hline Age (wks) & White Fulani & WF x ND & N'Dama $^{\prime}$ & SEM \\
\hline $60-72$ & 13.00 & 19.00 & 11.99 & 2.50 \\
$73-85$ & 13.10 & 19.10 & 11.99 & 2.50 \\
$86-98$ & 13.20 & 19.15 & 12.19 & 2.50 \\
$99-111$ & 14.19 & 19.25 & 12.19 & 2.45 \\
$112-124$ & $14.39^{\mathrm{b}}$ & $27.29^{\mathrm{a}}$ & $12.27^{\mathrm{c}}$ & 3.72 \\
\hline
\end{tabular}

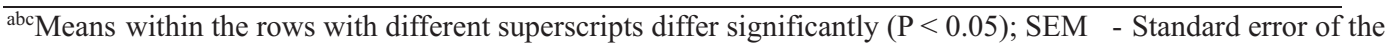
mean, WF x ND = White Fulani x N'Dama crosses 


\section{Characterization of indigenous cattle genotypes based on linear body traits}

\section{Conclusion}

The study has shown the characterization of local cattle based on quantitative traits. The results have shown that White Fulani and White Fulani $x$ N'Dama genotypes exhibited greater performance in growth parameters among the three genotypic groups. The White Fulani and White Fulani $\mathrm{x}$ N'Dama had better growth and longest body measurements. In view of the results obtained in this study, it is recommended that the White Fulani and crosses with N'Dama genotypes should be selected by breeders to achieve improved production, using the quantitative traits BL, EL, TL, and BL.

\section{References}

Blackmore D. W., McGulliard, L. D. and Lush, J. L. 1995. Genetic relationship between body measurements at three ages in Holstein. Journal of Dairy Science 41: 1045

Duncan, D. B. 1955. Multiple Range and Multiple F-tests. Biometrics 11: 142.

Gous, R. 1997. Understanding growth and carcass development. In: World's Poultry Science Elservier Publication 13:466-48.

Itty, P., Ankers, P., Zinsstag, J., Trawally, S. and Pfister, K. 1997. Productivity and Profitability of Sheep Production in the Gambia: Implications for Livestock Development in West Africa. Quarterly Journal of International Agriculture, 36: 153-172.

Nosike, R. J., Nwachukwu, E. N., Ibe, S. N., Obike, O. M. and Okoro, V. M. O. 2013. Relationship between biologic markers and quantitative traits in the domestic rabbit. Proc. $40^{\text {th }}$ Conference Nigerian Society for Animal Prod. Rivers State
Univ. of Science and Tech., Port Harcourt, Nig. Pp. 62-65.

Mendes, A. R., Ezequiel, J. M. B., Galati, R. L., Bocchi, A. L., Queiroz, M. A. A. and Feitosa, J. V. 2005. Intake, total and partial digestibility of diets with sunflower meal and three energy sources in confined steers. Rev. Bras. Zootec. 34 (2): 679-691

NRCRI 2017 National Root Crops Research Institute Umudike, Metereological station.

Nwachukwu, E. N., Nwankwo, C. U. and Akomah, C. 2011. AEarly growth performance and economic production of crossbred normal feather, frizzle and naked-neck pullets. Proc. $36^{\text {th }}$ Confr. Nig. Soc. for Anim. Prod. Univ. of Abuja, Nig. Pp. 74-77.

SPSS 2011. Statistical Package for Social Sciences. SPSS Inc. (16.0), 444 Michigan Avenue, Chicago.

Rege, J. E. O. and Tawah, C. L. 1999. The state of African cattle genetic resources II. Geographical distributions, characteristics and uses of present-day breeds and strains. FAO/UNEP Animal Genetic Resources Information Bulletin. 26:1-25.

Wilson, 1995. Understanding the Dairy Cow. Blackwell Scientific publications. London Edinburgh Boston 2nd Ed. Pp. 288-333.

Received: $17^{\text {th }}$ November, 2019 Accepted: $20^{\text {th }}$ February, 2020 